\title{
ELECTROPHYSIOLOGY AND MORPHOLOGY OF THE DEVELOPING HIPPOCAMPUS OF FETAL RABBITS ${ }^{1}$
}

\author{
PHILIP A. SCHWARTZKROIN*, $\ddagger^{2}$ AND DENNIS D. KUNKEL* \\ *Department of Neurological Surgery and $\ddagger$ Department of Physiology and Biophysics, University of Washington, \\ Seattle, Washington 98195
}

Received September 4, 1981; Revised November 4, 1981; Accepted December 11, 1981

\begin{abstract}
The pyramidal neurons of fetal rabbit hippocampus were studied using intracellular electrophysiological techniques in in vitro slice preparations. Correlative light and electron microscopic analyses were carried out on hippocampus during the 21st through the 29th day of fetal gestation. In intracellular experiments, neurons with all-or-none action potentials and near-adult level resting potentials were found even in the youngest preparations. Synaptic activity, however, was rare until about 24 days of gestation. CA1 neurons showed primarily excitatory synaptic potentials during fetal development, whereas CA3 neurons displayed both inhibitory and excitatory postsynaptic potentials at early stages. Anatomical studies suggested that pyramidal cell precursors were still dividing and migrating at 21 days; by 29 days, cellular migration was completed, and cellular intercommunication in the form of synapses was increasing.

These experiments demonstrate that fetal central nervous system (CNS) material can be studied electrophysiologically without growing tissue in culture. Our results suggest that the newly differentiated hippocampal neurons have a limited repertoire of activities. Such data may provide a link between in vivo studies of postnatal CNS development and cell and tissue culture investigations of the properties of immature neurons.
\end{abstract}

Modern anatomical techniques have allowed investigatcrs to study the morphological development of central nervous system (CNS) regions in great detail. These techniques, including radioactive labeling of dividing neurons, have been employed with great success in studying the hippocampal formation. Investigators have pinpointed the birth dates of various cell types in the many parts of rat, mouse, and rabbit hippocampus (Altman and Das, 1965; Angevine, 1965; Rayer and Altman, 1974; Fernandez and Bravo, 1974; Schlessinger et al., 1978; Stanfield and Cowan, 1979; Bayer, 1980a, b). Others, using Golgi techniques, also have described the time course and path of cell migration and differentiation in hippocampus (Stensaas, 1967a-e, 1968; Minkwitz and Holz, 1975; Minkwitz, 1976a-c).

Since much of this development occurs during fetal stages of life, it has been difficult to elucidate the physi-

\footnotetext{
'This work was supported by Grants NS 15317, NS 00413, and NS 04053 from the National Institute of Neurological and Communicative Disorders and Stroke, National Institutes of Health. Dr. Schwartzkroin is an affiliate of the Child Development and Mental Retardation Center, University of Washington.

${ }^{2}$ To whom correspondence should be addressed at Department of Neurological Surgery RI-20, University of Washington, Seattle, WA 98195 .
}

ological properties which parallel the morphological development. A few investigators (Purpura et al., 1968; Schwartzkroin and Altschuler, 1977; Schwartzkroin, 1982) have reported on the intracellular electrophysiology of developing hippocampus, but these studies have all begun at birth, a time when many of the most interesting developmental changes have already occurred. Electrophysiologists instead have turned to cell culture (Banker and Cowan, 1977; Peacock, 1979) and tissue culture (Crain et al., 1975; Gähwiler, 1980) techniques by which dissociated hippocampal neurons or pieces of hippocampal tissue may be maintained in vitro. For these studies, the hippocampus can be removed from animals at fetal stages, and cell growth and interconnections can be studied over time in the in vitro setting. Much valuable information has been gained with cell and tissue culture techniques (Dichter, 1975; Giacobini et al., 1980), but there is a need to relate the data obtained in such studies to as yet unexplored characteristics of immature fetal neurons in situ.

In the present studies, we have investigated the characteristics of hippocampal neurons from fetal rabbits. Intracellular recordings were obtained from tissue which was removed from fetal animals, sliced, and maintained in vitro. The neuronal activities recorded in these experiments reflect the cellular capabilities of hippocampal 
neurons at a known stage of development in their natural state of organization.

\section{Materials and Methods}

Surgery. Experiments were carried out on fetuses of Dutch belted and New Zealand white rabbits. Fetal ages ranged from 21 to 29 days of gestation (full term for rabbits is 30 to 31 days). Does at selected stages of pregnancy were anesthetized (halothane) and prepared for sterile surgery. The rabbit's abdominal cavity was opened, exposing the uterus. For each fetus removed, a separate incision was made in the uterus, the fetus was taken from its sac, the umbilical cord was clamped and cut, and the incision was closed. From each surgery, at least one fetus was taken for the purpose of electron microscopic examination and one for electrophysiological study. The muscle and skin incisions in the doe were sutured and the doe was allowed to recover. When fetuses were removed at a relatively early stage of gestation (prior to 26 days), attempts generally were made to remove older fetuses from the same doe at a later date. However, in most cases, the doe resorbed the remaining fetuses following the initial surgery, allowing only one age to be studied from each mother.

Preparations for electrophysiology. Following removal of a fetus from its mother, preparation of hippocampal slices proceeded essentially as described for -preparing hippocampal slices from postnatal animals (Schwartzkroin, 1982). The fetus's head was cut off and then cut sagittally along the midline with a scalpel blade. Working from the medial side of one half of the head, the cerebellum/brainstem regions were lifted out of the skull case, leaving a thin layer of cortex. The fimbrial edge of the hippocampus then could be visualized in what was to become the temporal lobe; using that landmark, the hippocampus then was dissected free. It was important to keep the brain moistened with cold $\left(4^{\circ} \mathrm{C}\right)$ bathing medium during this procedure to prevent the tissue from drying and becoming difficult to handle.

Once the hippocampus had been dissected from the brain, it was laid out on the stage of a tissue chopper (Sorvall), and transverse sections 500 to $700 \mu \mathrm{m}$ thick were cut. These sections were removed from the chopper blade with a fine brush, floated in cold bathing medium, and transferred to the mesh of the slice chamber with a wide mouth pipette. Slices were maintained at a fluid-gas interface. Bathing medium ( $\mathrm{NaCl}, 124 \mathrm{~mm} ; \mathrm{KCl}, 5 \mathrm{~mm}$; $\mathrm{NaH}_{2} \mathrm{PO}_{4}, 1.25 \mathrm{~mm} ; \mathrm{MgSO}_{4}, 2 \mathrm{mM} ; \mathrm{CaCl}_{2}, 2.25 \mathrm{~mm}$; $\mathrm{NaHCO}_{3}, 26 \mathrm{~mm}$; dextrose, $10 \mathrm{~mm}$ ) maintained at $35 \pm$ $0.5^{\circ} \mathrm{C}$ flowed beneath the slices, and a warmed and moistened gas mixture $\left(95 \% \mathrm{O}_{2}, 5 \% \mathrm{CO}_{2}\right)$ saturated the environment above the slices.

Recordings were made from cells in a visually identified pyramidal band of Ammon's horn using micropipettes filled with $4 \mathrm{M}$ potassium acetate (80 to $100 \mathrm{meg}-$ ohms). Intracellular records were obtained to measure resting potential, membrane resistance, charging time constant, and spiking properties. Current pulses, 100 msec in duration and of varying amplitude and polarity, were injected through the recording electrode into the cells via a bridge circuit. The cell response to synaptic activation was recorded following stimulation of the slice with bipolar sharpened tungsten electrodes (constant current pulses, $100 \mu \mathrm{sec}$ duration; 0.1 to $0.5 \mathrm{~mA}$ ). An attempt was made to move the stimulating electrode to a number of different locations to optimize the possibilities of eliciting responses. In a few experiments, some cells were impaled with electrodes containing Lucifer Yellow $\mathrm{CH}$ (3\% in water or in a $0.1 \%$ solution of lithium chloride) (Stewart, 1978).

Preparation for electron microscopy. Initial attempts to prepare fetal hippocampus for EM studies were carried out with immersion fixation of dissected hippocampus in $2 \%$ paraformaldehyde, $0.5 \%$ glutaraldehyde in $0.13 \mathrm{M}$ Millonig's phosphate buffer ( $\mathrm{pH} 7.4$; total perfusate osmolarity, $940 \mathrm{mOsm}$ ). In later experiments, fetuses were fixed by intracardial perfusion ( 150 to $200 \mathrm{ml}$ over $1 / 2 \mathrm{hr}$ ) of $2 \%$ paraformaldehyde, $0.5 \%$ glutaraldehyde in $0.1 \mathrm{M}$ sodium cacodylate buffer with $0.05 \% \mathrm{CaCl}_{2}(\mathrm{pH} 7.3,850$ mOsm). This latter fixation method gave much better preservation of neural structures. Brains were removed from the skull immediately, and hemispheres were separated and immersed in cold $\left(5^{\circ} \mathrm{C}\right)$ perfusate for $4 \mathrm{hr}$. The brain then was placed in $2 \%$ paraformaldehyde and $2 \%$ glutaraldehyde in $0.1 \mathrm{~m}$ sodium cacodylate for 12 to $16 \mathrm{hr}$ at $5^{\circ} \mathrm{C}$. To dissect out the hippocampus, the brainstem was removed, and 1- to 2-mm-thick horizontal sections were made parallel to the ventral surface of the brain. The hippocampal formation then could be clearly differentiated and separated from the overlying neocortex. Transverse sections of hippocampus $(0.5$ to $1.0 \mathrm{~mm}$ thick) were postfixed in $1.0 \% \mathrm{OsO}_{4}$ in $0.15 \mathrm{M}$ sodium cacodylate buffer for 1 to $1 \frac{1 / 2}{\mathrm{hr}}$ and then dehydrated in a graded ethanol series. Slices were embedded in Epon and then thin sections were cut and stained with uranyl acetate and lead citrate. Silver sections were placed on grids supported with parlodion and carbon and examined on a Philips EM 100 electron microscope.

Electron micrographs were taken of fields in the cell body and apical dendritic regions. These fields were taken at an initial magnification of $\times 8100$. In the cell body layer, micrographs were taken of fields which showed cell intersections and membranes in order to maximize the possibilities of finding somatic synapses. Approximately 15 fields were photographed in stratum pyramidale for each animal, with at least two sections examined per animal. Fields in the apical dendrites were photographed in a systematic manner: starting at $40 \mu \mathrm{m}$ from the apical edge of stratum pyramidale, fields were photographed in a vertical series progressing $40 \mu \mathrm{m}$ distally. When the series was completed, the field of focus was shifted parallel to the pyramidale layer past a yrid bar, and another series of fields was photographed. Fifteen micrographs per animal were taken in the apical dendritic region. For analysis, negatives were magnified $\times 2.5$ and counts of synapses were made from photographic prints. The number of synapses per unit area was computed.

\section{Results}

Table I shows the number of cells recorded in experiments with fetal rabbit hippocampus at various stages of development. No experiments were carried out on animals younger than 21 days gestation since, prior to this 
TABLE I Summary of electrophysiological experiments

\begin{tabular}{|c|c|c|c|c|c|}
\hline \multirow{2}{*}{ Age } & \multirow{2}{*}{ No. Experiments } & \multirow{2}{*}{ No. Cells } & \multicolumn{2}{|c|}{$R_{i}^{a}$} & \multirow{2}{*}{$\tau$ Range } \\
\hline & & & Mean & Range & \\
\hline days & & & \multicolumn{2}{|c|}{ megohms } & msec \\
\hline 21 & 2 & 26 & 160 & $60-460$ & $6.4-20$ \\
\hline 22 & 1 & 12 & & & \\
\hline 23 & 2 & 25 & 87 & $60-160$ & $8-16$ \\
\hline 24 & 2 & 24 & 80 & $49-90$ & $8-17$ \\
\hline 26 & 2 & 23 & 76 & $60-110$ & $8-16$ \\
\hline 28 & 2 & 37 & 68 & $36-120$ & $8.8-16$ \\
\hline 29 & 1 & 16 & & & \\
\hline
\end{tabular}

${ }^{a} R_{I}$, input resistance.

${ }^{b}$ Days of gestation.

time, the dissection, slicing, and recording from hippocampus were very difficult. A pyramidal cell region was visible at this stage of development, but it was not possible to determine the CA1-CA3 division until about 24 days gestation; recordings from the youngest animals therefore were not differentiated on this basis. For most penetrations, it was necessary to use a 0.5-nA DC hyperpolarizing "holding" current to prevent the cells from undergoing rapid depolarization and inactivation. As a result of using this holding current, cell resting potentials were difficult to determine accurately. In the best recordings, the holding current could be turned off before measurements were made. By "best," we mean penetrations that exceeded criteria established for mature hippocampus: resting potential $>55 \mathrm{mV}$, input resistance $>20$ megohms, a regular train of spike firing during depolarizing current pulse, and action potential amplitude $>55 \mathrm{mV}$ (Schwartzkroin, 1977, 1982).

The following descriptions are based on the best recordings obtained at the indicated ages and are not the average or mode. This method of anecdotal reporting was deemed appropriate because of the large number of cases in which penetrations clearly injured the cells, leading to depolarization, rapid inactivation of spiking, low input resistance, and other uninterpretable phenomena. Even given this selective reporting, it is clear that cell properties may have been altered significantly by the process of electrode penetration. Because of this technical problem, we cannot be sure that the reported data accurately represent cell properties or sequences of change. Somewhat arbitrary criteria have been established so that a description of cellular properties in this developing tissue could be offered.

21 to 23 days. Cells were extremely difficult to penetrate in these slices, presumably because of their small size. In most cases, when the electrode approached a cell, the cell discharged briefly and then was silent. Injection of hyperpolarizing holding current helped to restore some cell properties. In a few cells that could be studied without holding current, the cell resting potential exceeded $60 \mathrm{mV}$. Only rarely ( 3 of 51 cells) was stimulation of the slice (primarily in the stratum radiatum region) effective in eliciting a postsynaptic potential (PSP). These PSPs were brief (20 to $40 \mathrm{msec}$ ) and depolarizing in stable recordings.

Injection of depolarizing current pulses $(0.1$ to $0.5 \mathrm{n} \Lambda$ ) was the most effective means of eliciting spike discharge
(Fig. 1). A large majority of cells produced action potentials when depolarized in this way (Fig. $1, A, B$, and $D$ ), but a small number did not (Fig. $1 C$ ). This latter group did not appear to be injured more seriously than other cells, for the cells often had high input resistances; even with large depolarizations, however, no all-or-none spikelike events could be elicited. In the majority of penetra-

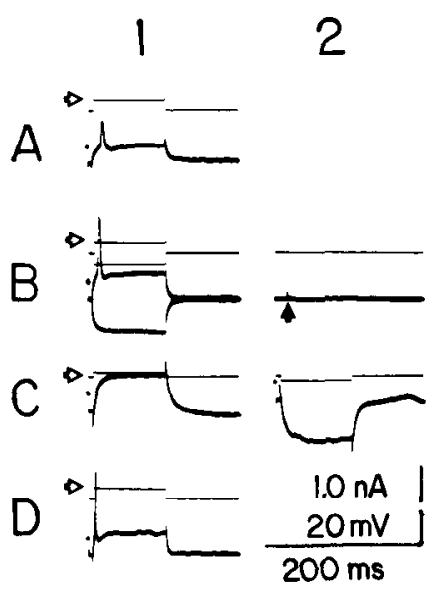

Figure 1. Selected recordings from 4 cells ( $A$ to $D$ ) of 21-daygestation fetal rabbit hippocampus. In this, and in all of the following figures, the top trace is a current monitor showing the amount of intracellularly injected current. The open arrow points to the 0 current level; hyperpolarizing current is down and depolarizing current is up. $A$, Typical example of cell activation with a $0.5-\mathrm{nA}$ current pulse. $B$, Effects of hyperpolarizing and depolarizing current (1). There was no observable response to orthodromic stimulation (solid arrow in 2). C, No spike activation was seen in this cell (1) despite its high input resistance (2). $D$, A current-activated action potential which is of high amplitude and shorter duration than that in $A$. Note that no cell fired repetitively to the $100-\mathrm{msec}$ depolarizing pulses.

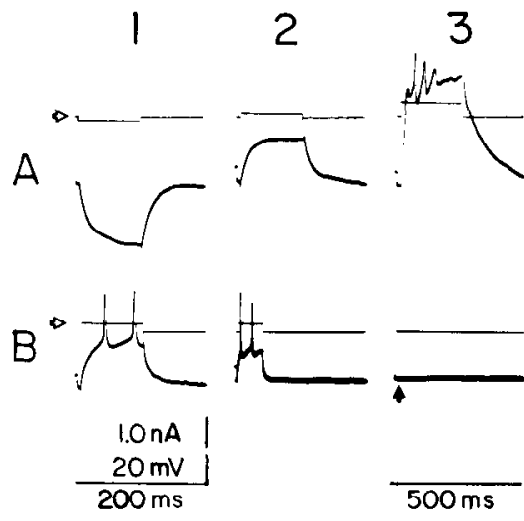

Figure 2. Two penetrations which appeared to be from uninjured neurons from 21-day-gestation fetal rabbit hippocampus. $A$, Cell with very high input resistance (over 400 megohms; 1 and 2). Repetitive discharge of broad, low amplitude spikes was achieved when the cell was depolarized sufficiently (3). No DC current was applied to this cell. $B$, Another cell in which more than one spike could be elicited by current injection (1). No afterhyperpolarization was seen after the burst (2). Orthodromic stimulation (solid arrow) produced no observable response (3). The 500-msec time calibration bar applies only to $B 2$ and $B 3$. 
tions, a single low amplitude, broad action potential was triggered with relatively short latency by the current pulse (Fig. 1A). These cells appeared to be injured (low input resistance, short time constant), and their inability to discharge repetitively seemed to be due to the injury associated with electrode penetration. It was more common to elicit repetitive spiking during the depolarizing current pulse in the 23-day-gestation tissue than in the 21-day-gestation tissue.

All of the action potentials recorded from cells at this period of development, even in the best penetrations (Fig. 2), were low amplitude (10 to $50 \mathrm{mV}$ ) and long duration (4 to $8 \mathrm{msec}$ ). Action potentials were blocked completely with a local droplet application of tetrodotoxin (TTX, $10^{-4} \mathrm{M}$ ) from a coarse micropipette positioned near the recording electrode. Repetitive spiking, when elicited by depolarizing current pulses, was not followed by afterhyperpolarizations (AHPs) in any of these cells (Fig. $2 B, 1$ and 2). Measurements of voltage deflections induced by hyperpolarizing current pulses indicated cell input resistances which ranged from 60 to 200 megohms (and up to 400 to 500 megohms in 2 cells at 21 days gestation; Fig. 2A1). Charging time constants (the time required for the cell membrane potential to reach $1-1 / e$ of its steady state value in response to a current step) ranged from 6.5 to 20 msec.

A small number of cells were filled with Lucifer Yellow during experiments on tissue from 21- and 22-day-gestation animals. Many of these injections resulted in the staining of multiple elements, but it was not clear if this staining was due to functional dye coupling among cells or artifactual dye spread caused by electrode damage (see "Discussion"). The electrophysiology for one injection which labeled a single cell (Fig. $3 C$ ) is illustrated in

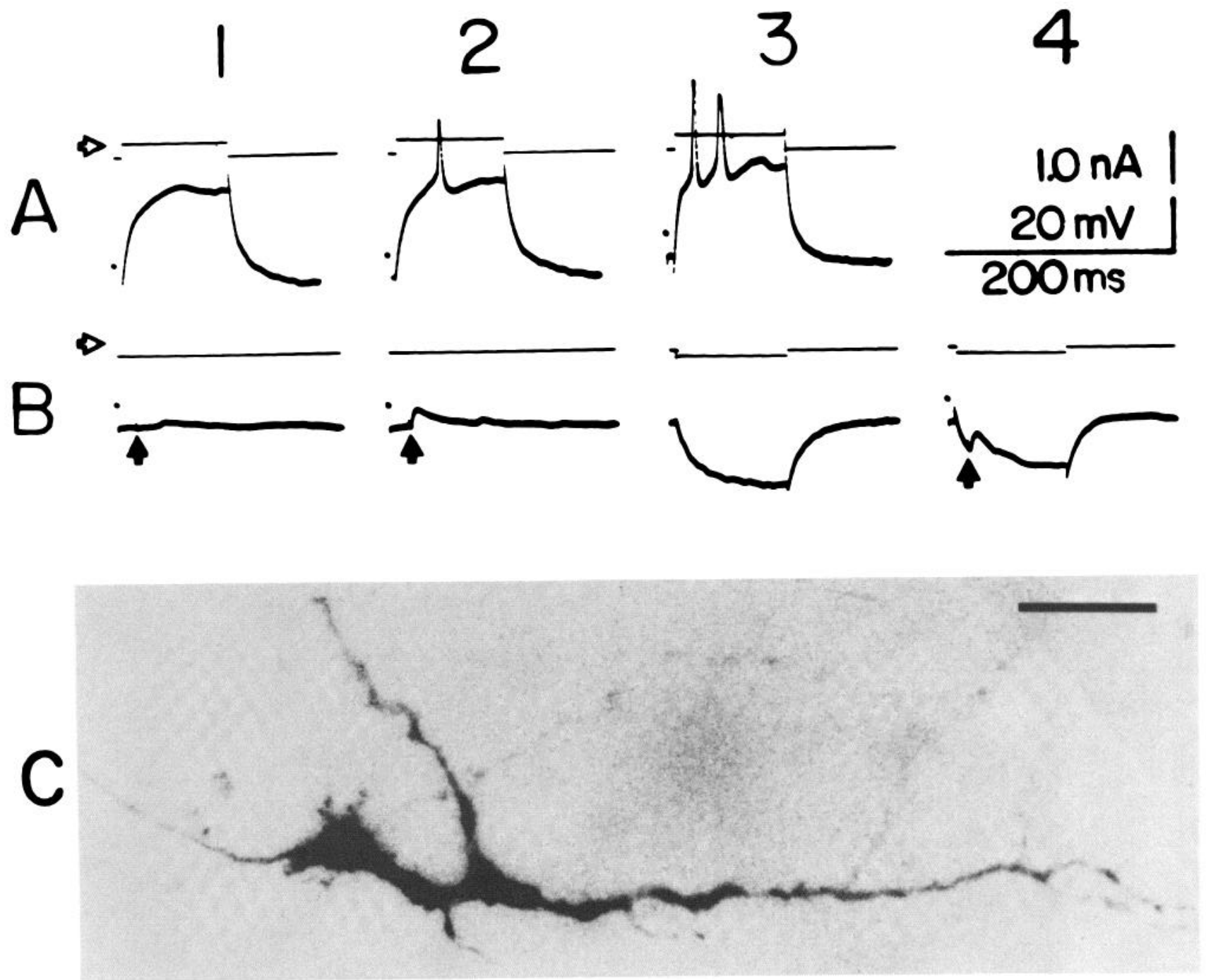

Figure 3. Electrophysiology and anatomy of a neuron from 21-day-gestation fetal hippocampus. $A$, Intracellular current injection could elicit action potentials. $B$, Orthodromic stimulation (solid arrows) evoked an apparent excitatory postsynaptic potential (EPSP) which increased in amplitude with more intense stimuli (1 and 2). B3 shows the membrane response to hyperpolarizing current, and $B 4$ shows the EPSP when stimulation was delivered during the hyperpolarizing response. $C$, Lucifer Yellow was injected into this cell, using a 4-min injection with a 1.0-nA hyperpolarizing current. The cell appears immature (i.e., does not resemble a pyramidal neuron) with multiple processes. Calibration bar, $30 \mu \mathrm{m}$. 
Figure 3, $A$ and $B$. The cells seen with these Lucifer Yellow injections looked different from cells in the mature hippocampus. Many had a multitude of processes which were recognizable as neither mature dendrites nor axons but which ramified profusely in spray-like endings. These profiles were similar to the neuroblasts described by Stensaas (1967d). As is clear from Figure 3, these cells could produce action potentials (Fig. $3 A, 2$ and 3 ) and even occasionally postsynaptic potentials (Fig. $3 B, 1,2$, and 4).

24 to 26 days. As was the case with the younger tissue, cells at this stage were extremely difficult to penetrate, and a holding current $(0.5 \mathrm{nA})$ was used routinely to maintain recordings. Stimulation of the slice resulted in distinguishable PSPs from about half of the cells in this age group. It was easier to obtain and maintain good penetrations from cells in regions thought to be CA3 than in CA1, and synaptic potentials were more frequent in the CA3 population. Recordings from CA3 neurons during slice stimulation also produced the first indications of the inhibitory PSPs (IPSPs), but such potentials were rare. The depolarizing PSPs, though of low amplitude when the cells were at resting potential (Fig. 4A3), were extremely sensitive to cell hyperpolarization produced by injection of negative current (Fig. 4B4). PSPs in hyperpolarized neurons could be large and of long duration (as long as 500 msec; Figs. 4, A3, B3, and C3 and $5, B 1$ and $C 1$ ). The PSPs were capable, in some neurons, of triggering action potentials (Figs. $4 B 1$ and $5 B 1)$.

Injections of pulses of depolarizing current were still the most effective way to trigger spike firing in these cells (Figs. $4 A 1$ and $5 A$ ). Action potentials were broad and of

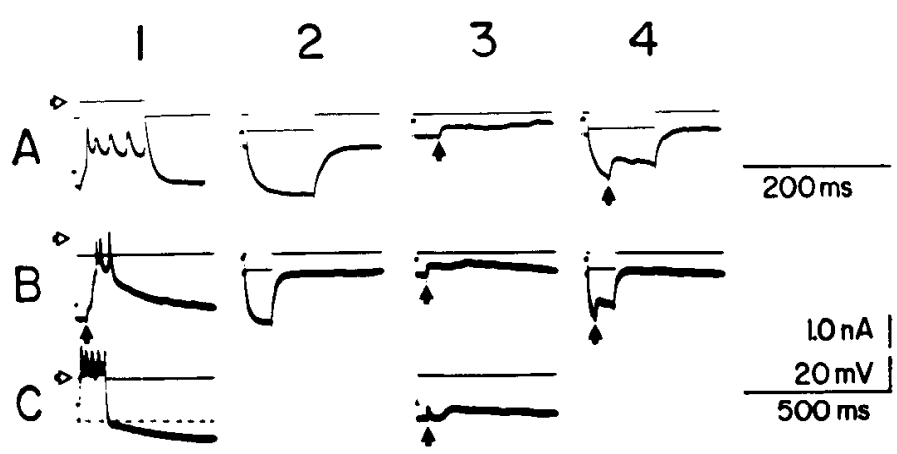

Figure 4. A cell penetrated in the $\mathrm{CA} 3$ region of 24-daygestation fetal rabbit hippocampus. $A$, The cell responded to an intracellular depolarizing pulse with repetitive firing of broad, low amplitude spikes (1), showed a high input resistance (2), and responded to orthodromic stimulation (solid arrows) with a long duration depolarizing PSP ( 3 and 4$)$. $B$, Slower sweep records of cell responses (cf., $A, 2$ to 4 with $B, 2$ to 4 ). $B 1$ shows an occasional burst response to orthodromic stimulation. The records in $A$ and $B$ were made with a DC holding current of $0.5 \mathrm{nA}$. $C$, No holding current. Repetitive firing induced by depolarizing current injection was followed by a long duration afterhyperpolarization (dashed line shows resting potential; 1). The response to orthodromic stimulation (3) was seen to have two components, a brief initial depolarization and a delayed depolarization of long duration. The time calibration bar following $A 4$ applies to $A$; the time calibration bar following $C 4$ applies to $B$ and $C$. low amplitude but were generated repetitively in a high proportion of cells. There were hints, in cells at this stage of development, of a significant calcium conductance. Depolarizing current pulses at levels subthreshold for spike initiation sometimes elicited broad, low amplitude humps, similar to events thought to be mediated by calcium in mature animals (Fig. 5A3) (Schwartzkroin and Slawsky, 1977). In addition, repetitive spiking elicited by depolarizing current often was followed by an extremely long duration afterhyperpolarization (cf., Hotson and Prince, 1980), particularly in CA3 cells (Fig. 4C1). Finally, the "anomalous rectification" attributed, at least in part, to inward calcium current in mature cells (Hotson et al., 1979) became apparent in a few neurons. This effect was manifested as a decrease in input resistance as the cell's membrane potential was made more negative with DC current (cf., Fig. 5, B2 and C2). Input resistance of these cells was high, ranging from 40 to 100 megohms (Fig. 5A); the charging time constant varied from 8 to 17 msec.

Lucifer Yellow injections into cells at this stage of development revealed neurons with long, thin apical dendrites which branched minimally (Fig. 5D). Basal processes were sparse, but a few primary basal dendrites were present. These cells appeared to be immature pyramidal cells (Stensaas, 1967e). The apical dendrites sometimes could be seen crossing apparent axon processes (Fig. $5 D$ ) or emerging from a dense mass of undifferentiated stained material.

28 to 29 days. Cells were somewhat easier to penetrate at this stage of development, but most penetrations continued to apparently injure the neurons; a 0.5 -nA holding current was again a standard tool for maintaining recordings. Synaptically evoked PSPs, from stimulation in stratum radiatum, were seen in most cells in which healthy resting potentials could be obtained. Long duration depolarizing PSPs were observed consistently in CA1 (Fig. 6), whereas a depolarizing-hyperpolarizing (EPSP-IPSP) sequence was evoked from many CA3 neurons (Fig. 7). Field potential "population spikes" also were recorded in response to slice stimulation (Fig. $8 B 4$ ). In a few CA3 cells, spontaneous PSPs could be observed to arise from resting base line, and an apparent unitary PSP was resolvable with very low intensity stimulation (Figs. $6 B$ and $8 B 1$ ). In addition, fast prepotential (FPP) activity (Schwartzkroin, 1977) was seen in a few cells, with FPPs triggered by the extracellular stimulation (Fig. 9A3). Repetitive extracellular stimulation, at $3 \mathrm{~Hz}$, led to a short term PSP facilitation in about half of the cells. In 2 neurons, such stimulation elicited afterdischarge and cell depolarization followed by stimulus-elicited bursts (similar to clonic discharge) (Fig. 10). Although these cells were inactivated during depolarization, no postictal depression was noted; cells returned to their normal discharge mode within $30 \mathrm{sec}$ following the afterdischarge.

Average spike amplitude was larger and average spike duration was shorter in neurons from tissue at this stage. These differences from the less mature cells could, of course, be attributable to less cell trauma caused by electrode penetration of the larger, more mature cells. For these cells of 28 to 29 days gestation, input resistance 

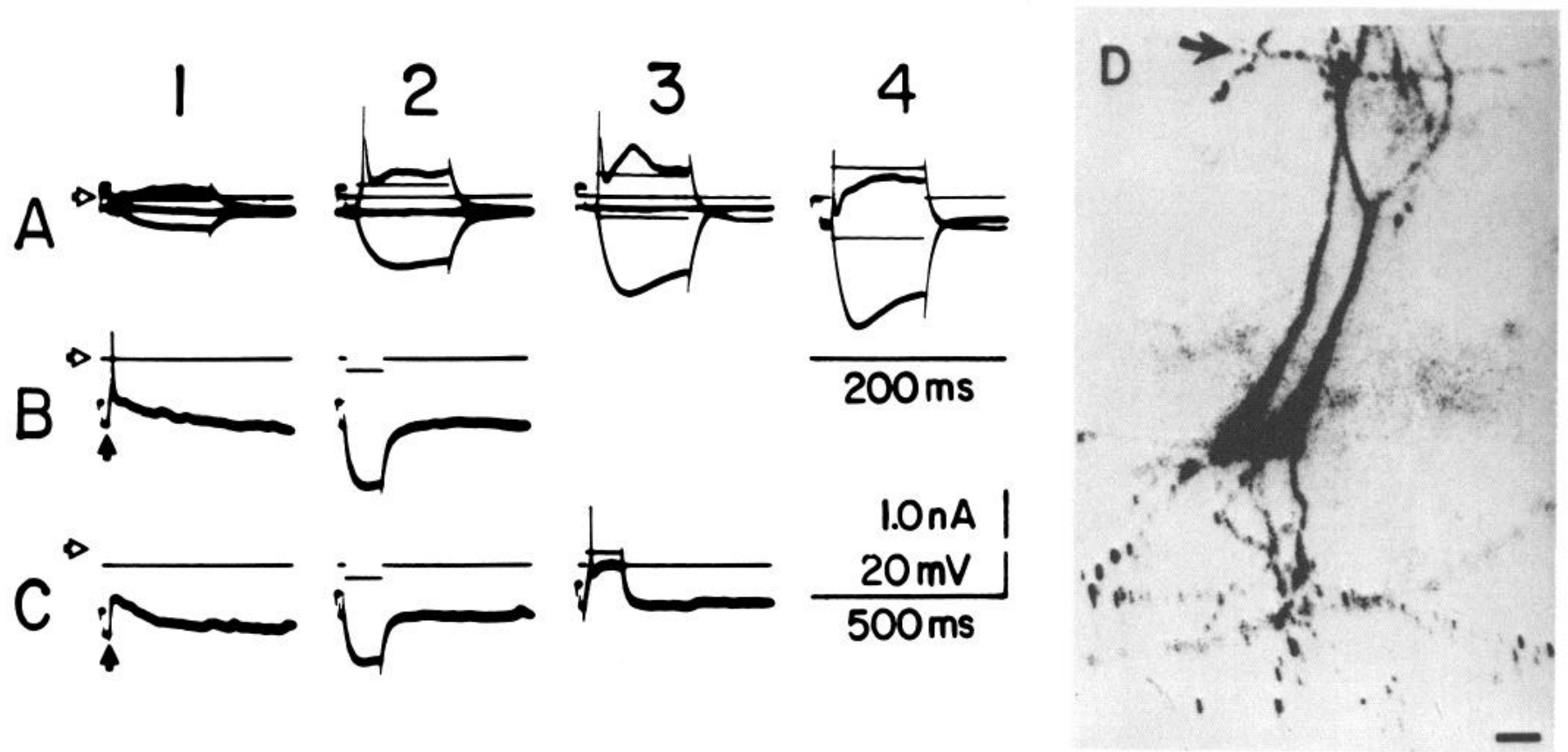

Figure 5. Recordings from a CA1 neuron from 26-day-gestation fetal rabbit hippocampus. $A$, Responses to gradually increasing amplitude depolarizing and hyperpolarizing pulses ( 1 to 4 ). Note the broad hump following the initial spike elicited by depolarizing current in 3. B, Orthodromic stimulation (solid arrow) elicited a long lasting depolarization and triggered a single spike discharge (1). Injection of a hyperpolarizing current pulse (2) revealed a high cell input resistance. The records in $A$ and $B$ were made with no DC holding current. $C$, Hyperpolarizing the cell with a 0.5-nA holding current blocked spike firing from the PSP (1). This hyperpolarization also demonstrated an "anomalous rectification" property; cell resistance was lower when the cell was hyperpolarized than when at normal resting potential (cf., $C 2$ and B2). The cell could still be activated with a depolarizing current pulse (3). $D$, Lucifer Yellow injection into a hippocampal cell of 26-day-gestation fetal rabbit. Two cells were labeled with a single injection. The simple elongated structure was typical of cells at this stage. Note that there is little branching of the apical dendrites and very poorly developed basal dendrites. The apical dendrites pass an apparent axonal process (arrow) running at right angles through their dendritic trees. Calibration bar, $30 \mu \mathrm{m}$.

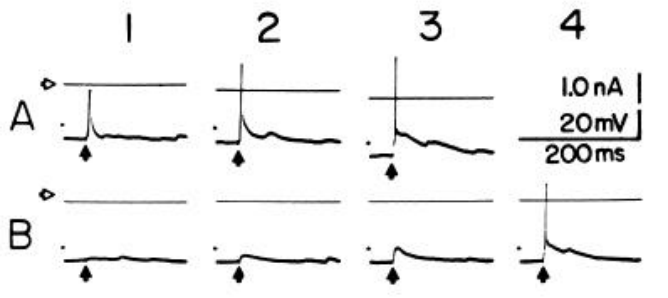

Figure 6. Recording from a hippocampal CA1 cell in 29-daygestation fetal rabbit. $A$, Orthodromic stimulation (solid arrow) evoked a long duration PSP and triggered spike discharge. Increasing cell resting potential by injecting hyperpolarizing current (increasing in 1 to 3 ) improved spike amplitude, decreased spike width, and made very clear the long lasting PSP. $B$, Increasing stimulus intensity, starting with just threshold strength for eliciting an EPSP (1) and increasing to spiketriggering strength (4). A $0.5-\mathrm{nA}$ DC hyperpolarizing current was injected during these recordings.

ranged from 30 to 120 megohms (e.g., Figs. $8 A$ and $9 B$ ) and the charging time constant ranged from about 9 to $17 \mathrm{msec}$. Intracellular depolarizing current pulses usually elicited trains of action potentials (Fig. $8 A$ ) followed by long duration ( $>2$-sec) AHPs (Fig. 9D). Hyperpolarizing pulses injected during the AHP showed a long lasting conductance increase associated with the hyperpolarization (Fig. 9C, 3 and 4). The AHP was also reversible with injection of DC hyperpolarizing current (Fig. $9 D, 2$ and

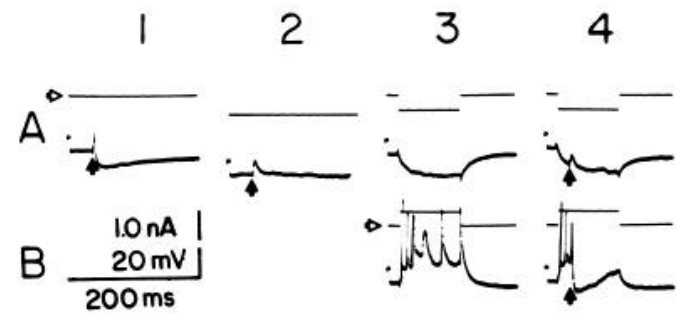

Figure 7. Recordings from a hippocampal CA3 neuron in a 29-day-gestation fetal rabbit. $A$, Response to orthodromic stimulus (solid arrow) with the cell at normal resting potential (1), hyperpolarized with a $0.5-\mathrm{nA}$ current (2), and superimposed in a hyperpolarizing current pulse (4) (response to hyperpolarizing pulse alone is shown in 3). In this cell, there was a clear EPSPIPSP sequence. $B$, The IPSP became particularly clear when the stimulus was superimposed during depolarizing current pulse (4). Note that the IPSP blocked spiking that normally occurred during the depolarization (cf., B3 and B4).

3). AHPs were dependent on prior activation of all-ornone potentials; if no spikes were elicited, even with a large membrane depolarization, no AHP would follow. This phenomenon was particularly dramatic in CA3 cells which would fire in a burst-like discharge in response to intracellular current injection (Fig. 9, A1, B3, C2, and C3). At the threshold for this response, the AHP could be seen only after cell discharge (Fig. 9C3). 
Anatomy. Hippocampus from fetal rabbits was clearly identifiable, showing the characteristic (although poorly developed) pyramidal cell layer even at 21 days of gestation. The size of the hippocampus increased dramatically between 21 and 28 days of gestation (Fig. 11). As

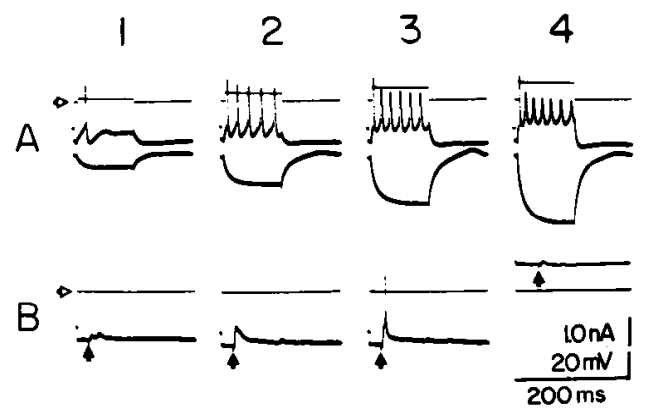

Figure 8. Recordings from a $\mathrm{CA} 3$ neuron in a 28-day-gestation fetal rabhit hippocampus. $A$, A series of increasing amplitude depolarizing and hyperpolarizing current pulses ( 1 to 4 ). This cell fired repetitively in a steady spike train upon depolarization and showed a high input resistance. $B$, Increasing the intensity of the orthodromic stimulus (solid arrow) from just threshold for a PSP (1) to spike driving (3). A field potential population spike was visible when the electrode was removed from this cell (4).

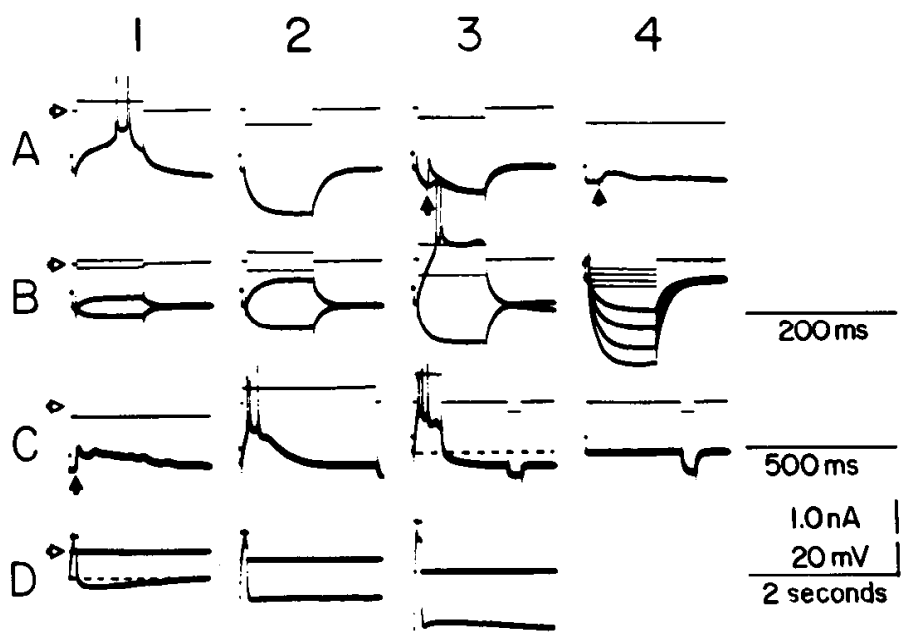

Figure 9. Recordings from a CA3 neuron from a 28-daygestation fetal rabbit hippocampus. $A$, Cell response to depolarizing (1) and hyperpolarizing (2) current and to an orthodromic stimulus (solid arrow; 3 and 4). Note the apparent fast prepotential triggered by the stimulus in $3 . B, A$ series of depolarizing and hyperpolarizing current pulses, showing the cell's high input resistance and relatively linear current-voltage relationship. The time calibration bar in $B$ also applies to $A$. $C$, The cell responded to an orthodromic stimulus with a very long lasting PSP, a response not obvious in $A 4$ but clearly brought out when the cell was hyperpolarized $(C 1)$. The response to depolarizing current pulses consisted of a brief burst of spikes followed by a hyperpolarization; this burst response was particularly apparent with long duration depolarizing pulses (C2). The afterhyperpolarization following current-induced firing was associated with a long lasting conductance increase (cf., C3 and 4). The dashed line shows the resting potential. $D$, The afterhyperpolarization (1) was reversible with the intracellular injection of hyperpolarizing current ( 2 and 3 ). gross hippocampal dimensions increased, the number and density of cells in the pyramidal cell layer also increased (Table II). At the earliest stages studied (21 days gestation), a large number of dividing cells were seen at the ventricular surface; no identifiable granule cell layer was visible. By 24 days gestation, the ventricular cell layer was less significant, and cell profiles were seen to be rather scattered throughout the region between the ventricular border and the pyramidale cell layer; a poorly organized dentate region was just forming. At 28 days gestation, the vast majority of cellular elements were contained within the pyramidal cell layer; a clear but small granule cell layer was also apparent.

Table II provides some measurements of the dimensions of the pyramidal cell layer and of the cells within it; these data are compared with that from 2-day postnatal and adult rabbits. Note that, in this and the following tables, CA1 and CA3 are distinguished even at 21 days of gestation. In these young animals, it was not always clear that a distinction could be made between CAl and CA3 neurons histologically, but this nomenclature was retained to refer to relative parts of the pyramidale cell layer (CA1, parallel to the dorsal surface; $\mathrm{CA} 3$, within the rostral-medial curve; Fig. 11). It is clear that, although the dimensions of individual neurons do increase, the change in cell size is rather small prenatally. Rather, the number of cells within the pyramidale increases, resulting in an increasing pyramidal cell layer width. Extracellular space also appeared to decrease as cell density increased. CA1 cells initially (21 to 24 days gestation) were observed to possess only short apical dendrites and few secondary dendritic branches. Dendritic development was more obvious at 24 to 28 days, with the apical dendrite elongating and more secondary branches appearing.

Synaptic development. Synaptic contacts were counted in the electron micrographs of cell body and apical dendritic regions of the pyramidal cell regions (Fig. 12). The area chosen for anatomical study corresponded to that region from which electrophysiological data were gathered and approximated the CAl region of more mature animals. Counts of synaptic profiles in these regions included only those contacts which showed a postsynaptic density, a clear synaptic cleft, and at least one presynaptic vesicle (Fig. 13D). The many appositions and membrane thickenings that did not meet these criteria were not included in the data summarized in Table III, although these contacts may include many "immature" synapses (Figs. 13, $A$ and $C$ and 14, $A$ and $E)$.

The upper part of Table III presents the density of synapses from the CA1 area of fetal animals from 21 to 28 days of gestation; at least two animals were analyzed from each age group. Synapses at the cell body layer were rare (Fig. 13B) and did not increase in number very much during the week of development studied here. There were many times more synapses in the apical dendritic region. After an initial significant increase between 21 and 24 days gestation, the number of dendritic synapses appeared to level off (note the large variability in the count at 26 days gestation). Most contacts were asymmetric, with round vesicles observed presynaptically, and occurred between axon terminals and small 


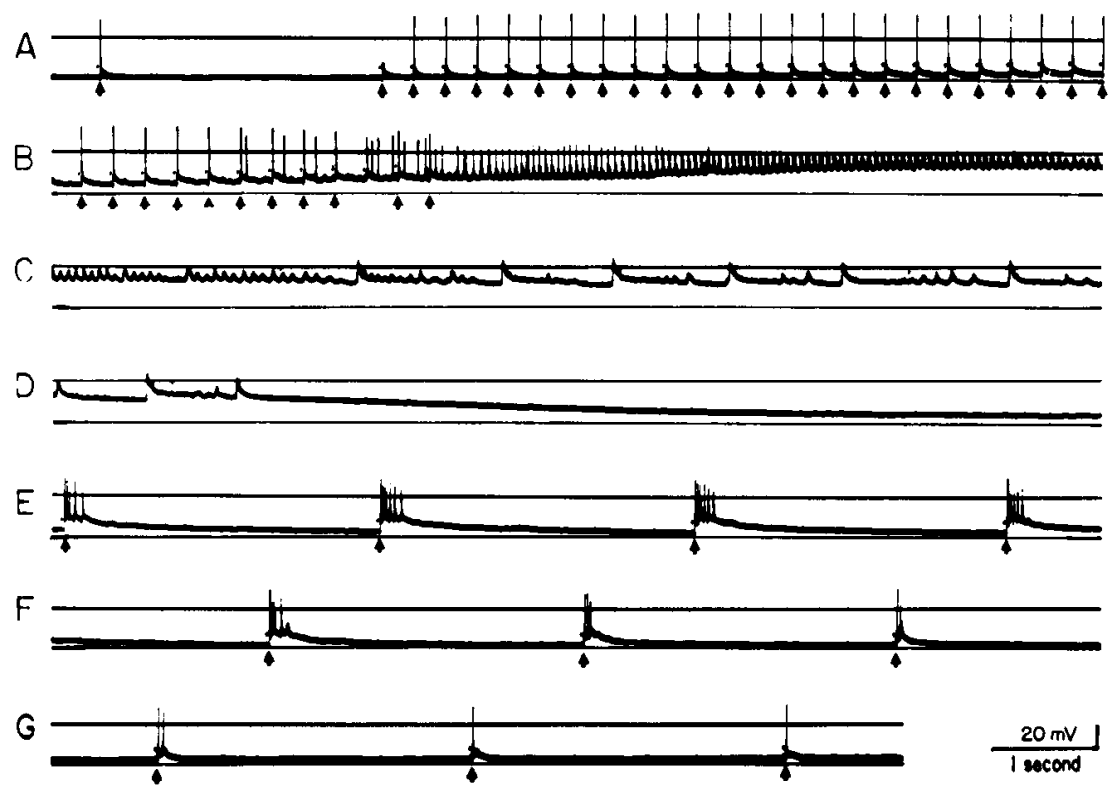

Figure 10. Continuous recording of a seizure episode from a CA3 neuron from a 28-day-gestation fetal rabbit hippocampus. $A$, Repetitive orthodromic stimulation (intensity just suprathreshold for spike firing; solid arrow) was increased from 0.3 to $3 \mathrm{~Hz} . B$ and $C$, The stimulation led to gradual cell depolarization and tonic cellular discharge even when the stimulus was discontinued. $C$ and $D$, Clonic discharges were followed by the cell repolarizing toward its initial resting potential. $E$ and $F$, Stimulation at $0.3 \mathrm{~Hz}$ continued to evoke burst discharges. $G$, Although the cell membrane potential never returned all the way to the initial base line (horizontal line below trace), stimulation did elicit responses similar to those seen before the seizure episode.

dendritic shafts (Fig. 13D). Occasional multiple contacts were observed (Figs. $13, E$ and $F$ and $14 B$ ) as were synapses onto swollen portions of dendrites or small dendrite stubs (Fig. 14D). The majority of contacts which could be counted clearly as synapses were similar in dimension to synapses of postnatal pups and adult rabbits (Table IV); however, fewer vesicles were visible in the presynaptic terminals of the fetal cells than in the adults (Table IV).

Electrophysiological data indicated that synaptic potentials (particularly IPSPs) were observed in the CA3 region earlier than in the $\mathrm{CA} 1$ region. Therefore, synaptic counts were made in the CA3 region of a limited number of animals at 21,24 , and 28 days gestation. These data are given in the lower part of Table III. Because the sample here is so small, no variability measure is given with the means. There were more synapses on the apical dendrites in CA 3 than in CA1 by the time these animals reached 24 days gestation. Changes in synapse number at the cell body of CA3 neurons, while particularly relevant to the development of inhibition seen electrophysiologically, are not apparent from our limited anatomical data. However, "finger-like projections" (Fig. 14, $E$ and $F$ ), often surrounded by an axon terminal could be seen on the proximal apical dendrites. These projections may represent the beginnings of postsynaptic mossy fiber synapse specializations (the granule cell region has become established by this age). Occasional large (0.7- to $1.5-\mu \mathrm{m})$, long synapses on major dendrites were seen in 28- to 29-day-gestation tissue (Fig. 14C); the presynaptic terminals were filled with round vesicles and seemed likely to be mossy fiber endings.

\section{Discussion}

The physiology and morphology of fetal rabbit hippocampus have been studied in an attempt to (1) provide data descriptive of the early stages of neuronal development within the hippocampus and (2) to establish with the in vitro slice preparation a bridge between developmental studies carried out in vivo and studies of neuronal properties carried out with cell and tissue culture techniques. Complementary electrophysiology and anatomy from our study suggest a relatively simple system which grows increasingly more complex over the period of a single week in fetal development.

Our studies show that the developing hippocampal neurons of rabbit, even as early as 21 days of gestation, display many of the electrical properties that characterize mature neurons. These cells, the majority of which are immature pyramidal neurons, maintain a near-adult level resting potential $(\sim 60 \mathrm{mV}$ in fetal tissue compared to 65 to $70 \mathrm{mV}$ in mature tissue) and show a high input resistance. Mean input resistance in the latest fetal stage studied here (68 megohms at 28 days gestation) was considerably higher than input resistances measured in early postnatal stages (40 to 55 megohms in the 1st week postnatal) and significantly higher than the adult mean of $\sim 22$ megohms (Schwartzkroin, 1982). Although the majority of impaled cells could generate action potentials, their spikes were broader and of lower amplitude 

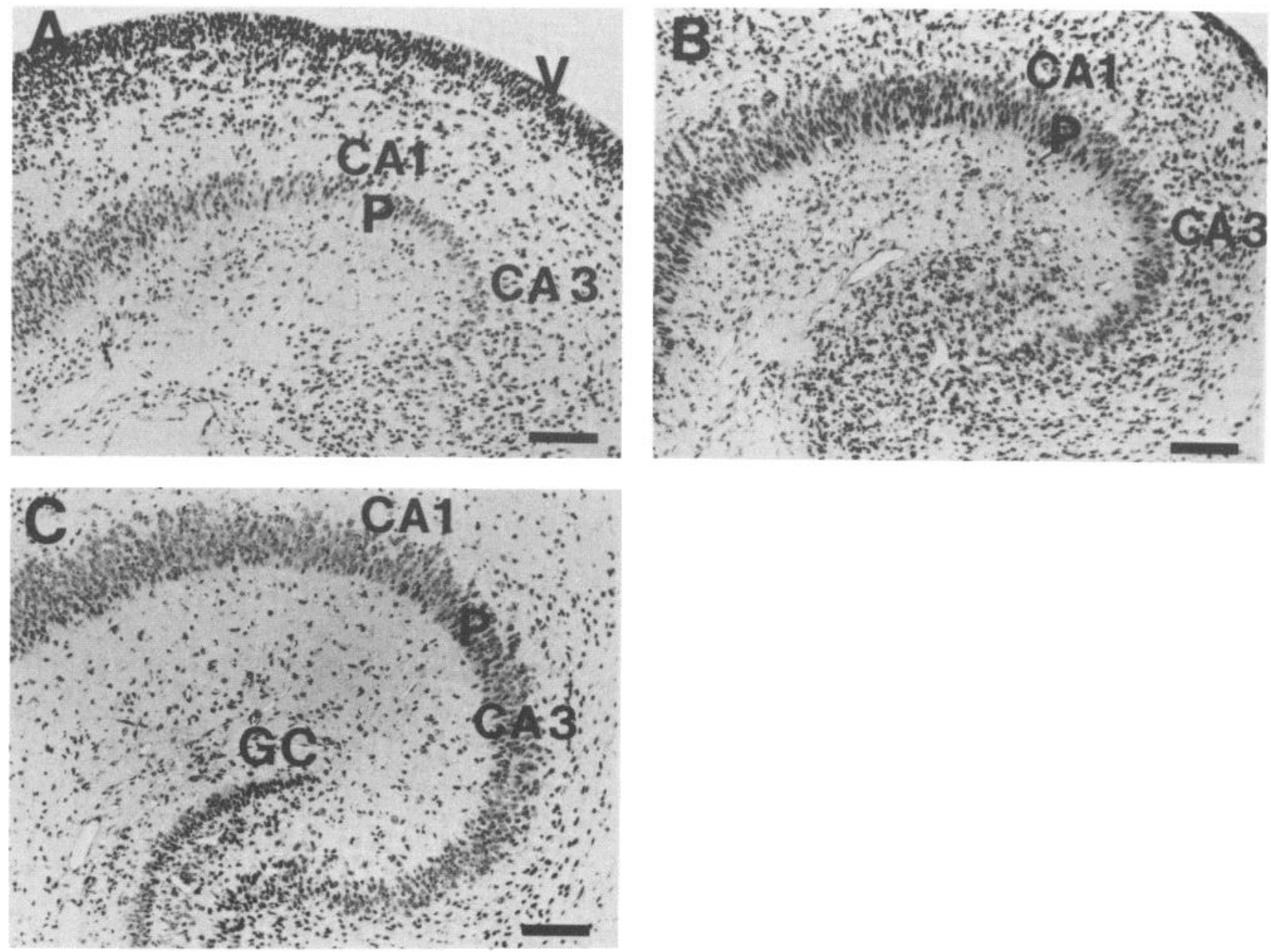

Figure 11. Light micrographs of hippocampal sections of fetal rabbits at $21(A), 24(B)$, and $28(C)$ days of gestation. Note the large increase in the size of the entire structure and the development of the pyramidal cell layer. At 21 days gestation, many cells were seen at the ventricular border $(V)$; by 28 days gestation, most cells were concentrated within stratum pyramidale $(P)$, which had become a band 5 or 6 cells wide. The dentate region, which contained few neurons at 21 days, showed a distinct band of granule cells $(G C)$ by 28 days.

TABLE II

Pyramidal cell size and packing density

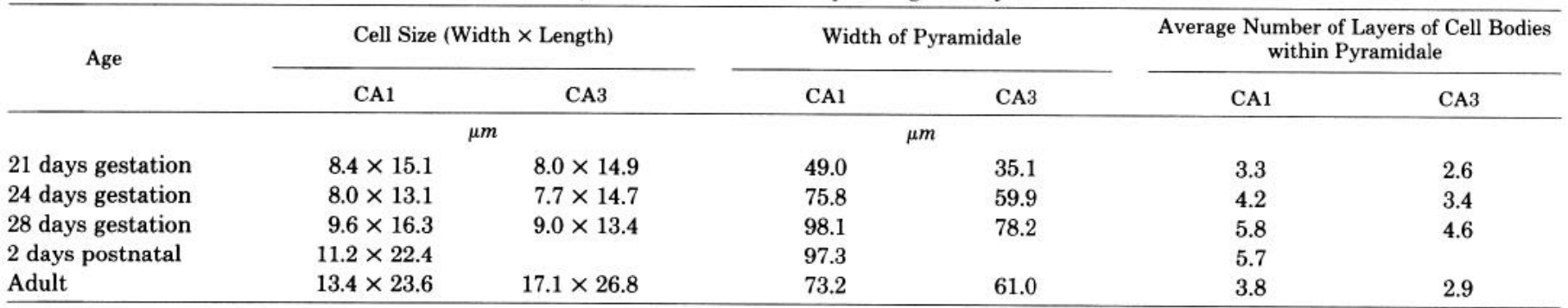

than those in the postnatal pup or the adult. During the time that we studied, action potential amplitude increased and the duration decreased. Neurons, which rarely fired repetitively at the younger stages, were capable of steady discharge in response to depolarizing current by 29 days gestation. In newborn rabbits, virtually all healthy hippocampal neurons displayed repetitive firing capabilities. Input resistance appeared to decrease during the last week of fetal development; given that the cells' time constants remained relatively constant (even compared to postnatal measures), the change in input resistance is probably attributable to an increase in cell size.

There were some indications that, as these cells matured, a calcium-mediated process appeared which was similar to that described in studies of adult hippocampal cell physiology. In studies of postnatal rabbit hippocampus, TTX-resistant potentials, probably attributable to calcium influx, were observed at the earliest stages examined (Schwartzkroin, 1982). However, in these fetal studies, broad current-elicited humps, suggestive of calcium spike electrogenesis (Schwartzkroin and Slawsky, 

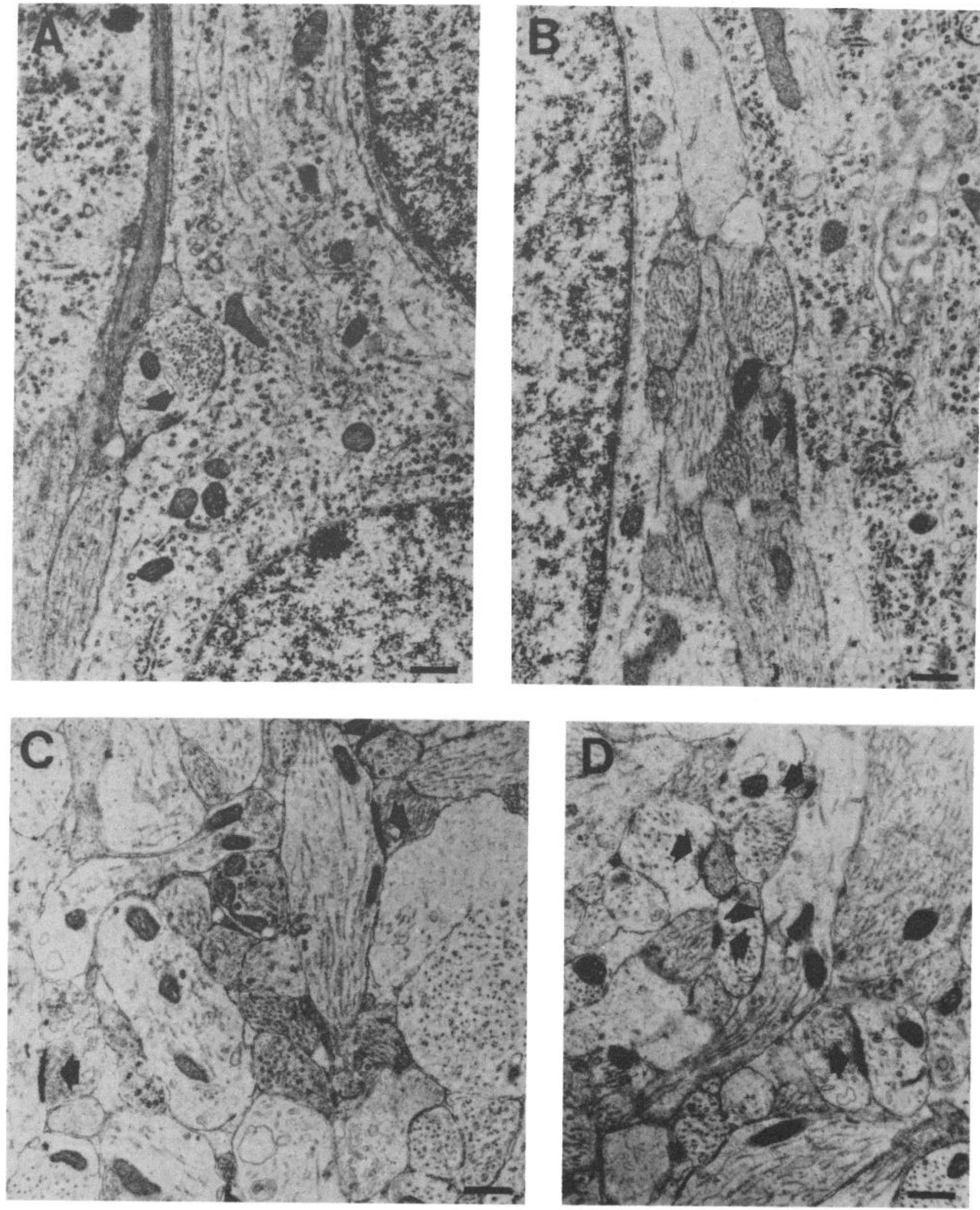

Figure 12. Low magnification electron micrographs of somatic ( $A$ and $B$ ) and apical dendritic $(C$ and $D)$ fields in the CA1 $(A$ and $C$ ) and CA3 $(B$ and $D)$ regions of fetal rabbit hippocampus at 24 days of gestation. The arrows indicate synapses with presynaptic vesicles and membrane thickenings. Calibration bars, $0.5 \mu \mathrm{m}$.

1977) could not be elicited from CA1 neurons until 24 days gestation. Extremely long lasting hyperpolarizations following repetitive spiking were seen starting at this age (particularly in CA3 neurons) and appeared to be pre- cursors of calcium-dependent potassium afterhyperpolarization (Hotson and Prince, 1980). Interestingly, the slow hyperpolarizations were associated with long lasting conductance increases and could be inverted by hyperpolar- 
izing current injection. These data suggest that the AHP was due to membrane ion fluxes and not to activation of a membrane ionic pump.

The need for studies of fetal hippocampal cell development became apparent during our examination of CA1 neurons in postnatal rabbit hippocampus. Even in newborn rabbits, almost all CA1 neurons had functional synaptic inputs (Schwartzkroin, 1982). Since we were interested in tracing the development of synaptic activity from its very beginnings, it became necessary to study the fetal preparation. Synaptic activity was rarely observed in the fetal preparation before 24 days gestation. As was the case for the postnatal rabbit pup (Schwartzkroin, 1982), synaptic activity in the fetal rabbit appeared to be primarily of a depolarizing type (particularly in CA1). The interpretation of these depolarizations as excitatory postsynaptic potentials (EPSPs) is consistent both with their excitatory function (spike triggering) and with the paucity of electron microscopic evidence for membrane profiles associated with inhibitory synapses (see also Schwartz et al., 1968; Schwartzkroin et al., 1982). These depolarizing PSPs were clearly different from the PSPs recorded from CA3 cells at later stages of fetal development ( 28 to 29 days gestation) and interpreted as IPSPs. The latter potentials were sharply hyperpolarizing and capable of abolishing ongoing spiking activity, just as are IPSPs in mature neurons.

It should be noted that many of the mature features of hippocampal cell electrophysiology were observed earlier, or exclusively, in CA3 neurons. When comparing fetal cells to their mature counterparts, it appears that CA3 neurons attain the adult CA3 characteristics at an earlier age than CA1 neurons attain adult CA1 characteristics. In addition to the IPSP mentioned above, repetitive neuronal discharge, long afterhyperpolarizations, and afterdischarge were seen in $\mathrm{CA} 3$ at younger ages than in CA1. This earlier maturation of CA3 neuronal properties is consistent with the earlier birth date of these cells (Schlessinger et al., 1978).

From the anatomical data, the earliest fetal stages that we studied (21 to 24 days of gestation) appear to be primarily a period of cell migration from the proliferating ventricular layer into stratum pyramidale, with rather limited cell growth or elaboration. During this time, the density of cells in stratum pyramidale increases markedly. Somewhat later (26 to 29 days of gestation and into postnatal development), cell complexity (number of branches, spines) increases, and the occurrence of synaptic contacts rises sharply. This later stage thus appears to be a period when the neurons are establishing connectivity among themselves.

The occurrence of dye coupling in preparations in which Lucifer Yellow was injected intracellularly is dif- ficult to interpret. Both Andrew et al. (1981) and Funch et al. (1981) have reported high percentages of dye-coupled neurons in adult hippocampus when Lucifer Yellow was injected into CA1 neurons. However, whereas Andrew et al. (1981) interpret this result as an accurate reflection of functional electrotonic coupling among CA1 neurons, Funch et al. (1981) maintain that most of this dye coupling could be due to technical artifact associated with the labeling method. The technical difficulties which might lead to artifactual dye coupling-cell injury, simultaneous impalement of more than 1 neuron, dye leakage-are magnified in immature tissue where cells are smaller and more closely packed together. The functional significance of the dye coupling observed in these studies and the possibility that single cell electrical measures are "contaminated" by either natural or electrodeinduced coupling cannot be assessed presently (as is also the case for mature tissue).

The developing neurons of rabbit fetal hippocampus, as studied in the slice preparation, are somewhat different from the neurons described in hippocampal cell cultures or organ cultures. We have observed much less spontaneous synaptic activity (Peacock, 1979) and less cellular connectivity (both electrophysiologically and neuroanatomically; Peacock, 1979), and we have rarely observed the bursty paroxysmal activity that seems so common in culture (Zipser et al., 1973; Peacock, 1979). Our anatomical studies, too, show the fetal cells to be relatively simple; they show limited branching of the apical dendrites and very few synaptic contacts on the somas. This picture of fetal hippocampal neurons is similar to the morphological description of cultured hippocampal neurons at the time of plating (Banker and Cowan, 1977; Peacock et al., 1979) but rather different from the complex, multiprocess cells which characterize the cultures which have been described electrophysiologically (Peacock et al., 1979).

TABLE III

Numbers of synapses in fetal hippocampus

\begin{tabular}{cccc}
\multicolumn{4}{c}{ Numbers of synapses in fetal hippocampus } \\
\hline Region & Ages & Cell Body Region & Apical Dendritic Region \\
\hline \multirow{2}{*}{ CA1 } & days ${ }^{\prime \prime}$ & \multicolumn{2}{c}{ synapses $/ 100 \mu m^{2}$} \\
& 21 & $0.131 \pm 0.097^{\circ}$ & $1.558 \pm 0.440$ \\
& 24 & $0.139 \pm 0.007$ & $2.461 \pm 0.485$ \\
& 26 & $0.130 \pm 0.006$ & $3.194 \pm 0.906$ \\
& 27 & $0.139 \pm 0.007$ & $2.368 \pm 0.087$ \\
& 28 & $0.149 \pm 0.034$ & $2.659 \pm 0.308$ \\
CA3 & & & \\
& 21 & 0.125 & 0.685 \\
& 24 & 0.249 & 3.427 \\
& 28 & 0.125 & 4.424 \\
\hline
\end{tabular}

"Days of gestation.

${ }^{b}$ The values represent the average $\pm \mathrm{SD}$.

Figure 13. Higher magnification electron micrographs of synaptic (or incipient synaptic) contacts. $A$, Somatic apposition (arrow) in CA3 of a 24-day-gestation fetal rabbit. Such contacts, with membrane thickenings but no synaptic vesicles, were common in the fetal material. B, Synaptic contact (arrow) with synaptic vesicles on a CA3 somatic membrane in a 24 -daygestation fetal rabbit. $C$, Immature contact (with no vesicles) on a CAl cell soma is shown at the bottom left (arrow). Another contact, with nearby vesicles, is at the upper right (arrow) at 24 days gestation. $D$, High magnification micrograph of a dendritic asymmetric synapse (arrow) in CAI at 24 days gestation. $E$, Dendritic profile in the apical dendrites of CAl showing a single synaptic terminal contacting two separate postsynaptic elements (arrows) at 27 days gestation. $F$, A single postsynaptic element in the CA1 dendritic region receiving contacts from at least three separate presynaptic terminals (arrous) at 26 days gestation. Calibration bars, $0.5 \mu \mathrm{m}$. 

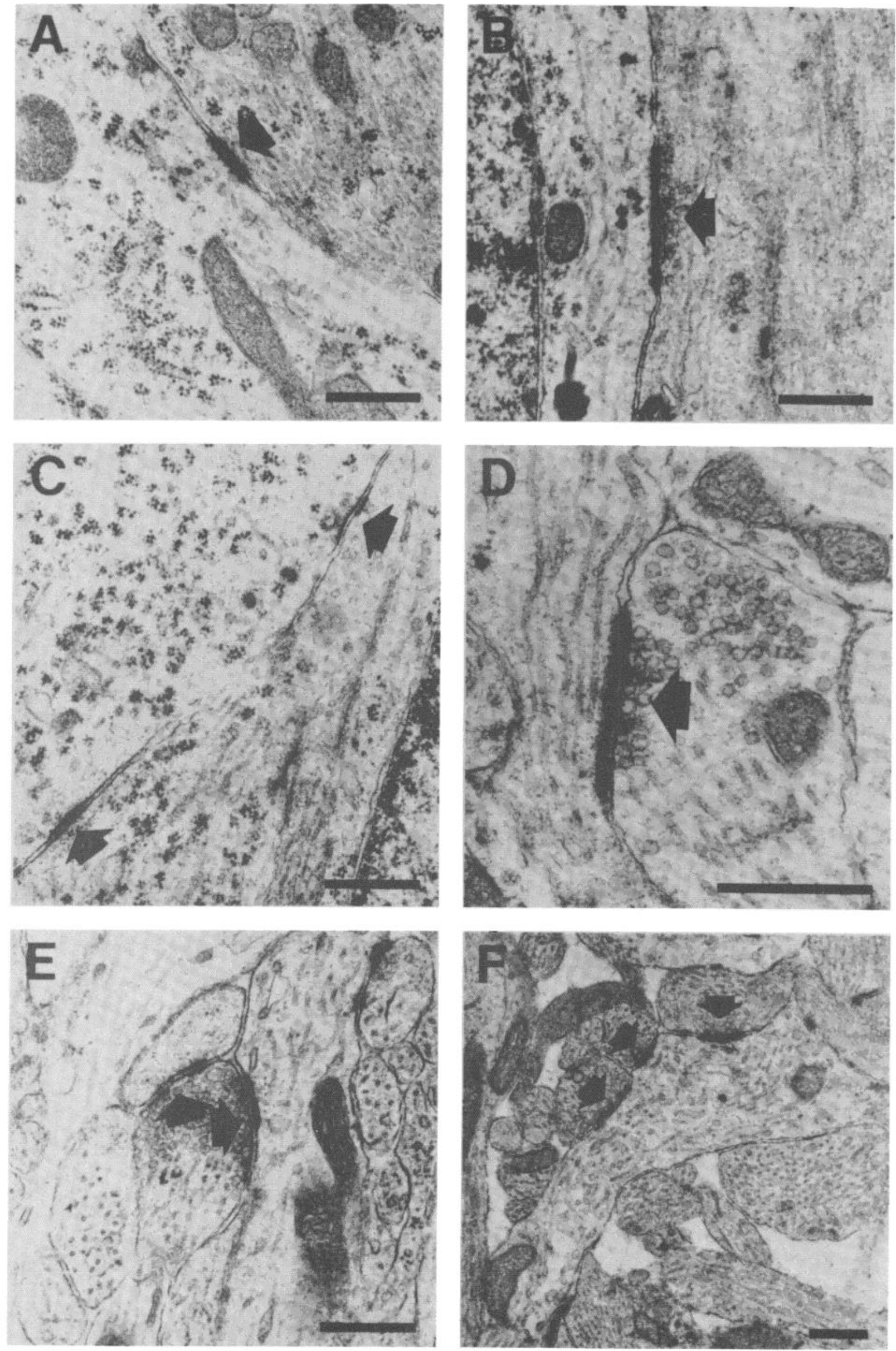

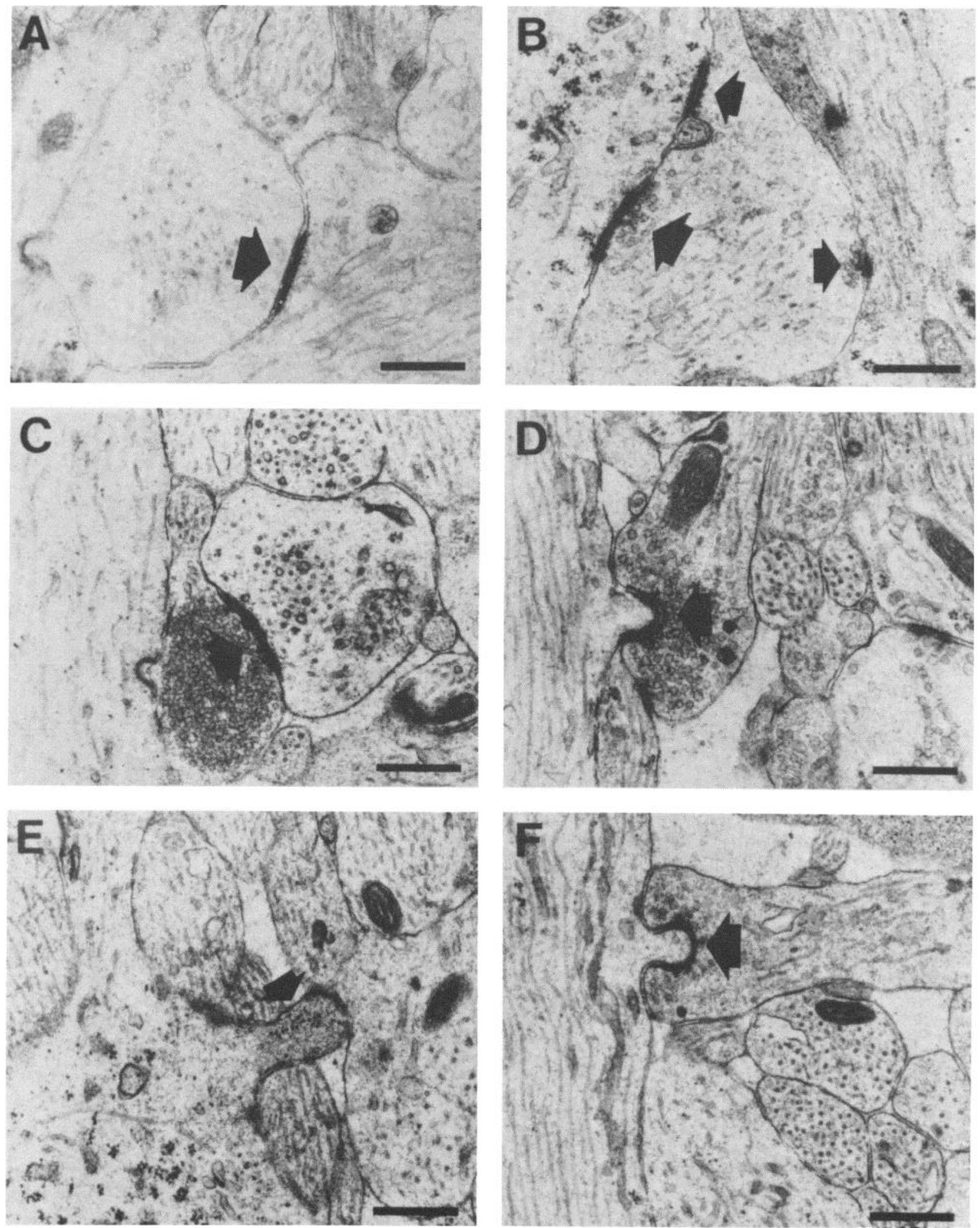

Figure 14. Synaptic specializations found in the CA3 dendritic region of fetal rabbit hippocampus. $A$, Immature contact (arrow) with no associated vesicles at 24 days gestation. $B$, Large synapse, with three contact sites (arrows) at 24 days gestation. $C$, Terminal packed with vesicles making a synaptic contact (arrow). Such terminals might be developing mossy fiber terminals at 27 days gestation. $D$, Synaptic contact onto a dendritic stub (arrow). In this micrograph and that in $F$, it appears as though the presynaptic element is starting to engulf the postsynaptic protrusion, characteristic of mossy fiber terminals, at 27 days gestation. $E$, Possible immature spine (arrow) without a clear synaptic contact at 27 days gestation. $F$, Synaptic contact on a spine-like protrusion from a major dendritic shaft at 27 days gestation. Calibration bars, $0.5 \mu \mathrm{m}$. 
TABLE IV

Size of asymmetric synaptic contacts and number of vesicles per terminal

\begin{tabular}{ccc}
\hline Age & Contact Length & Vesicles/Terminal \\
21 days gestation & $\mu m$ & \\
24 days gestation & $0.33 \pm 0.09^{\alpha}$ & $11.63 \pm 6.62$ \\
28 days gestation & $0.55 \pm 0.13$ & $15.68 \pm 7.82$ \\
& & $17.05 \pm 8.61$ \\
2 days postnatal & $0.48 \pm 0.11$ & $23.38 \pm 10.07$ \\
8 days postnatal & $0.43 \pm 0.10$ & $25.10 \pm 12.04$ \\
14 days postnatal & $0.42 \pm 0.11$ & $26.03 \pm 11.67$ \\
Adult & $0.41 \pm 0.10$ & $35.48 \pm 15.93$ \\
\hline
\end{tabular}

"The values represent the average $\pm \mathrm{SD}$.

This picture of fetal hippocampus arising from the in vitro slice preparation should complement the data derived from cell culture studies and provide additional insights into the cellular and synaptic properties of developing hippocampal neurons.

\section{References}

Altman, J., and G. D. Das (1965) Autoradiographic and histological evidence of postnatal hippocampal neurogenesis in rats. J. Comp. Neurol. 124: 319-335.

Andrew, R. D., C. P. Taylor, R. W. Snow, and F. E. Dudek (1981) Dye-coupling between CA1 pyramidal cells in rat hippocampal slices. Soc. Neurosci. Abstr. 7: 519.

Angevine, J. B., Jr. (1965) Time of neuron origin in the hippocampal region. Exp. Neurol. Suppl. 2: 1-70.

Banker, G. A., and W. M. Cowan (1977) Rat hippocampal neurons in dispersed cell culture. Brain Res. 126: 397-425.

Bayer, S. A. (1980a) Development of the hippocampal region in the rat. I. Neurogenesis examined with ${ }^{3} \mathrm{H}$-thymidine autoradiography. J. Comp. Neurol. 190: 87-114.

Bayer, S. A. (1980b) Development of the hippocampal region of the rat. II. Morphogenesis during embryonic and early postnatal life. J. Comp. Neurol. 190: 115-134.

Bayer, S. A., and J. Altman (1974) Hippocampal development in the rat: Cytogenesis and morphogenesis examined with autoradiography and low-level X-irradiation. J. Comp. Neurol. 158: 55-80.

Crain, S. M., C. S. Raine, and M. B. Bornstein (1975) Early formation of synaptic networks in cultures of fetal mouse neocortex and hippocampus. J. Neurobiol. 6: 329-336.

Dichter, M. (1975) Physiological properties of vertebrate nerve cells in tissue culture. In Brain Mechanisms in Mental Retardation, N. Buchwald and M. Brazier, eds., pp. 101 114, Academic Press, New York.

Fernandez, V., and H. Bravo (1974) Autoradiographic study of development of the cerebral cortex in the rabbit. Brain Behav. Evol. 9: 317-332.

Funch, P. G., W. D. Knowles, and P. A. Schwartzkroin (1981) Absence of electrical coupling in dye-coupled pyramidal cells in the CA1 region of guinea pig hippocampus. Soc. Neurosci. Abstr. 7: 519.

Gähwiler, B. H. (1980) Excitatory action of opioid peptides and opiates on cultured hippocampal pyramidal cells. Brain Res. 194: 193-203.

Giacobini, E., A. Vernadakis, and A. Shahar, eds. (1980) Tissue Culture in Neurobiology, Raven Press, New York.

Hotson, J. R., and D. A. Prince (1980) A calcium activated hyperpolarization follows repetitive firing in hippocampal neurons. J. Neurophysiol. 43: 409-419.

Hotson, J. R., D. A. Prince, and P. A. Schwartzkroin (1979)
Anomalous inward rectification in hippocampal neurons. J. Neurophysiol. 42: 889-895.

Minkwitz, H. -G. (1976a) Zur Entwicklung der Neuronenstruktur des Hippocampus während der prä-und postnatalen Ontogenese der Albinoratte. I. Mitteilung: Neurohistologische Darstellung der Entwicklung langaxoniger Neurone aus den Regionen CA3 and CA4. J. Hirnforsch. 17: 213-231.

Minkwitz, H. -G. (1976b) Zur Entwicklung der Neuronenstruktur des Hippocampus während der prä-und postnatalen Ontogenese der Albinoratte. II. Mitteilung: Neurohistologische Darstellung der Entwicklung von Interneuronen und des Zusammenhanges long-und kurzaxoniger Neurone. J. Hirnforsch. 17: 233-255.

Minkwitz, H. -G. (1976c) Zur Entwicklung der Neuronenstruktur des Hippocampus während der prä-und postnatalen Ontogenese der Albinoratte. III. Mitteilung: Morphometrische Erfassung der ontogenetischen Veränderungen in Dendritenstruktur und Spinebesatz an Pyramidenneuronen (CA1) des Hippocampus. J. Hirnforsch. 17: 255-275.

Minkwitz, H. -G., and L. Holz (1975) Die ontogenetische Entwicklung von Pyradimidenneuronen aus dem Hippocampus (CA1) der Ratte. J. Hirnforsch. 16: 37-54.

Peacock, J. H. (1979) Electrophysiology of dissociated hippocampal cultures from fetal mice. Brain Res. 169: 247-260.

Peacock, J. H., D. F. Rush, and L. H. Mathers (1979) Morphology of dissociated hippocampal cultures from fetal mice. Brain Res. 169: 231-246.

Purpura, D. P., S. Prelevic, and M. Santini (1968) Postsynaptic potentials and spike variations in the feline hippocampus during postnatal ontogenesis. Exp. Neurol. 22: 408-422.

Schlessinger, A. R., W. M. Cowan, and L. W. Swanson (1978) The time of origin of neurons in Ammon's horn and the associated retrohippocampal fields. Anat. Embryol. (Berl.) 154: 153-173.

Schwartz, I. R., G. D. Pappas, and D. P. Purpura (1968) Fine structure of neurons and synapses in the feline hippocampus during postnatal ontogenesis. Exp. Neurol. 22: 394-407.

Schwartzkroin, P. A. (1977) Further characteristics of hippocampal CA1 cells in vitro. Brain Res. 128: 53-68.

Schwartzkroin, P. A. (1982) Development of rabbit hippocampus: Physiology. Dev. Brain Res. 2: 469-486.

Schwartzkroin, P. A., and R. J. Altschuler (1977) Development of kitten hippocampal neurons. Brain Res. 134: 429-444.

Schwartzkroin, P. A., and M. Slawsky (1977) Probable calcium spikes in hippocampal neurons. Brain Res. 135: 157-161.

Schwartzkroin, P. A., D. D. Kunkel, and L. H. Mathers (1982) Development of rabbit hippocampus: Anatomy. Dev. Brain Res. 2: 453-468.

Stanfield, B. B., and W. M. Cowan (1979) The development of the hippocampus and dentate gyrus in normal and reeler mice. J. Comp. Neurol. 185: 423-460.

Stensaas, L. J. (1967a) The development of hippocampal and dorsolateral pallial regions of the cerebral hemisphere in fetal rabbits. I. Fifteen millimeter stage, spongioblast morphology. J. Comp. Neurol. 129: 59-70.

Stensaas, L. J. (1967b) The development of hippocampal and dorsolateral pallial regions of the cerebral hemisphere in fetal rabbits. II. Twenty millimeter stage, neuroblast morphology. J. Comp. Neurol. 129: 71-84.

Stensaas, L. J. (1967c) The development of hippocampal and dorsolateral pallial regions of the cerebral hemisphere in fetal rabbits. III. Twenty-nine millimeter stage, marginal lamina. J. Comp. Neurol. 130: 149-162.

Stensaas, L. J. (1967d) The development of hippocampal and dorsolateral pallial regions of the cerebral hemisphere in fetal rabbits. IV. Forty-one millimeter stage, intermediate lamina. J. Comp. Neurol. 131: 409-422.

Stensaas, L. J. (1967e) 'The development of hippocampal and 
dorsolateral pallial regions of the cerebral hemisphere in fetal rabbits. V. Sixty millimeter stage, glial cell morphology. J. Comp. Neurol. 131: 423-436.

Stensaas, L. J. (1968) The development of hippocampal and dorsolateral pallial regions of the cerebral hemisphere in fetal rabbits. VI. Nincty millimeter stage, cortical differentiation. J. Comp. Neurol. 132: 93-108.
Stewart, W. W. (1978) Functional connections between cells as revealed by dye-coupling with a highly fluorescent naphthalimide tracer. Cell 14: 741-759.

Zipser, B., S. M. Crain, and M. B. Bornstein (1973) Directly evoked "paroxysmal" depolarization of mouse hippocampal neurons in synaptically organized explants in long-term culture. Brain Res. 60: 489-495. 